\title{
POOR RICHARD'S PRINCIPLE
}





\section{POOR RICHARD'S PR I N C I P LE}

RECOVERING THE AMERICAN DREAM THROUGH THE MORAL

DIMENSION OF WORK, BUSINESS, AND MONEY

ROBERT WUTHNOW

PRINCETON U N IVERSITY PRESS P R I NCETON, NEW JERSEY 
Copyright (c) 1996 by Princeton University Press

Published by Princeton University Press, 41 William Street,

Princeton, New Jersey 08540

In the United Kingdom: Princeton University Press,

Chichester, West Sussex

All Rights Reserved

Library of Congress Cataloging-in-Publication Data

Wuthnow, Robert.

Poor Richard's principle : recovering the American dream

through the moral dimension of work, business, and money /

Robert Wuthnow.

p. $\mathrm{cm}$.

Includes bibliographical references and index.

eISBN 1-4008-0879-0

1. United States-Moral conditions. 2. Work-Moral

and ethical aspects-United States. 3. Money-Moral and

ethical aspects-United States. 4. Business ethics-

United States. 5. Social values-United States.

6. Work and family-United States. I. Title.

HN90.M6W87 1996

306'.0973-dc20 96-6799

This book has been composed in Palatino 
And everywhere, through the immortal dark, something moving in the night, and something stirring in the hearts of men, and something crying in their wild unuttered blood, the wild unuttered tongues of its huge prophecies-so soon the morning, soon the morning: $\mathrm{O}$ America.

Thomas Wolfe, The Web and the Rock 
